\title{
Enhancing Mate Selection through the Internet: A Comparison of Relationship Quality between Marriages arising from an Online Matchmaking System and Marriages arising from Unfettered Selection.
}

\author{
Steven R. Carter ${ }^{1}$ \\ eHarmony.com, Pasadena, $C A$ \\ J. Galen Buckwalter \\ eHarmony.com, Pasadena, CA
}

\begin{abstract}
The current work investigates the effects of a broadly adopted online matchmaking site on the nature and quality of married couples formed. Measures of personality, emotion, interests, values and marital adjustment were collected from a sample of married couples who had been introduced by an online matchmaking service, and from a sample of married couples who had met through unfettered choice. Results showed that couples introduced by the online matchmaking site were more similar, and that such similarity in general using the current measures was a strong predictor of marital adjustment in both online matched and comparison couples. Marriages resulting from the online matchmaking service were observed to have significantly higher scores for marital adjustment. We conclude that online matchmaking services based on predictive inference and proscribed selection can be observed to have a significant and meaningful impact on marital quality.
\end{abstract}

Keywords: Mate selection, Internet, marriage quality, online matchmaking.

Research examining the root causes of marital success or failure in America has largely shifted away from a focus on attributes present at the commencement of the marriage (Adams, 1946; Burgess \& Cottrell, 1939; Burgess \& Wallin, 1953; Terman \& Buttenweiser, 1938) to a more recent focus on the behaviours and interactions existing within marriage (Gottman \& Notarius, 2000; Kim, Copaldi \& Crosby, 2007; Schulz, Brennan, Cowan \& Cowan, 2004; Smith, Vivian and O'Leary, 1990). Shifting from an

\footnotetext{
${ }^{1}$ Authors Notes: The reader should be aware that the authors are employed by, and have a financial interest in the success of, eHarmony.com, Inc. Correspondence concerning this article should be sent to Steve Carter, Senior Director of Research and Development, eHarmony.com, 888 East Walnut St., 2nd Floor, Pasadena, CA 91101. e-mail scarter@eharmony.com. This work would not have been possible without the assistance of Jackie Martin.
} 
emphasis on predicting marital outcomes to an emphasis on identifying and describing relationship dynamics which comprise problems within marriages is consistent with the rise and acceptance of behavioural marital therapy in the 1970's (Karney \& Bradbury, 1995). The development of a plethora of marital therapies, theories and self-help manuals aimed at couples and individuals trying to improve the quality of their existing relationship or marriage has also been consistent with this trend toward deemphasising potentially unalterable traits of the relationship partners and focusing instead on relational dynamics as the primary means of improving marriage satisfaction and success. Romantic partners and spouses, typically compared to randomly paired individuals, have been found to be more similar to each other across a number of characteristics. Such evidence of assortative trends in mate selection has been observed in regards to physical and psychological traits, psychological abilities, interests, gender role orientation, and demographic characteristics such as race, ethnic origin, religion and social class (Anderson, Keltner, \& John, 2003; Bouchard \& McGue, 1981; Feng \& Baker, 1994; Feingold, 1988; Hollingshead, 1950; Huston \& Houts, 1998). Further, the degree of similarity has been demonstrated to predict level of marital quality. The importance of similarity, often referred to as homogamy, within married couples has been observed in most studies that have examined patterns of difference between partners' personalities as they relate to marital quality. The same is not found for complementarity, the condition when partners differ on a characteristic. Although complementarity has occasionally been shown to have value (Gattis, Berns, Simpson \& Christensen, 2004; Shiota \& Levenson, 2007), across several decades of research efforts, the overwhelming majority of findings have shown that couples exhibiting higher degrees of relationship quality, measured in a number of ways, tend towards similarity on psychological states and traits (Antill, 1983; Acitelli, Kenny, \& Weiner, 2001; Fowers \& Olson, 1992; Gaunt, 2006; Gonzaga, Campos, \& Bradbury, 2007; Kurdek, 1993; Luo \& Khlonenen, 2005; Murstein \& Williams, 1985; Richard, Wakefield \& Lewak, 1990; Russell \& Wells, 1991; Tharp, 1963).

The theoretical perspective underlying the online matchmaking paradigm is that who you are and who you choose to be with will have an enormous impact on the quality of your marriage. Matchmaking services also assume it is possible to affect your selections when looking for a mate in a way that will improve on the outcome in a manner that would likely not occur without intervention. This marks a potential shift in focus back to the mate selection characteristics of singles when searching for a 
relationship partner. Some such services also argue that the process of mate-selection can be enhanced by applying findings from research on the attributes of successful relationships to the process of identifying potential matches among their base of single users. While this process does not have any direct implications for research directed toward relationship dynamics within marriages, it does bring to the fore the literature on individual characteristics as they predict relationship quality.

The current study provides a test of this theoretical perspective by drawing comparisons between married couples whose selection of a partner was constrained by an online matchmaking system and married couples whose selection was made in an unfettered environment. Although specific details of the matching models used are not examined in this paper, the online system under evaluation may be accurately understood at a broad level to create pairings based on a schema of maximizing the intra-dyad levels of traits observed in empirical research to be positively related to marriage quality, and minimising intra-dyad differences on traits where similarities have been observed to be positively related to marriage quality. It is also noteworthy that the matchmaking system providing married couples for the present study applies models developed through the observation of married couples to singles seeking a mate in an online environment.

Study of the comparison between marriages that result from online matchmaking and those that arise from naturalistic meeting and selection allows us to address two unique research questions. First, can an online match-making system be observed to significantly impact the qualities of dyads, and especially the qualities that are thought to be related to long-term relationship success? Although a great deal of research has examined what types of choices singles make when searching for a mate, little or no work has examined how malleable these choices are. Second, can couples who married after being matched based on traits measured before their introduction be seen to score objectively higher than comparison couples in terms of the quality of their marriage relationship some years later? Again, the implication for many decades has been that increasing the similarity of couples at the outset of marriage should improve their relationship outcome. However, little previous work has tested this theory.

We advance three hypotheses. First, it is hypothesised that the online matchmaking system being tested had a systematic effect on the partner selections made by users, resulting in couples that have greater internal similarity than comparison couples where there was no matchmaking treatment applied to their selection 
opportunities. Second, it is hypothesised that similarity within couples will be related to marital quality. Finally, it is hypothesised that significant benefits to systematically pairing singles before they engage in selection using an online matchmaking service will be observed in regards to marital quality per previous findings (Carter \& Snow, 2004).

\section{Method}

\section{Participants}

Couples were recruited who were either known to have been matched by an online matchmaking system (eHarmony.com), or who were members of an online panel of US residents self-identified as interested in participating in online research. Couples who met through the online matchmaking system had identified themselves to the investigators as a married or engaged couple between September 2003 and October 2007. This company encourages couples who met after being introduced through the service to inform them of their engagement or marriage through announcements on their website, email campaigns, and incentives such as vacation sweepstakes and contests. This panel has been a source of participants for two previous waves of research in 2003 (Carter \& Snow, 2004) and 2005. About half of the current participants from the online matchmaking service had participated in previous research waves. Participant couples were paid the equivalent of $\$ 40$.

Comparison couples were recruited via a commercial vendor of research samples (Survey Sampling International [SSI]). All comparison participants were required to be currently married and at least 18 years of age. In total, 4,204 people participated in the current study, of which 2,124 comprised couples matched by the online system (i.e. Online Matched) and 2,080 comprised couples who had met without the help of a matchmaking system (i.e., Comparison). Demographics for the Online Matched and Comparison participants are shown below in Table 1). 
Table 1

Demographics for Overall Sample

\begin{tabular}{|c|c|c|c|c|c|c|}
\hline \multirow[b]{2}{*}{ Measure } & \multicolumn{4}{|l|}{ Online } & \multicolumn{2}{|c|}{ Total $(n=4204)$} \\
\hline & Mean & SD & Mean & SD & Mean & SD \\
\hline$\overline{\text { Age }}$ & 40.84 & 10.39 & 40.93 & 9.68 & 40.88 & 10.04 \\
\hline Age at Marriage & 38.49 & 10.43 & 26.53 & 9.89 & 32.57 & 11.80 \\
\hline Years Married & 2.35 & 2.84 & 14.40 & 11.30 & 8.31 & 10.17 \\
\hline Measure & Count & $\%$ & Count & $\%$ & Count & $\%$ \\
\hline \multicolumn{7}{|l|}{ Education } \\
\hline Doctorate & 135 & $6.36 \%$ & 33 & $1.59 \%$ & 168 & $3.00 \%$ \\
\hline Masters & 509 & $23.96 \%$ & 147 & $7.07 \%$ & 656 & $15.60 \%$ \\
\hline Bachelors & 790 & $37.19 \%$ & 478 & $22.98 \%$ & 1268 & $30.16 \%$ \\
\hline Associates & 205 & $9.65 \%$ & 245 & $11.78 \%$ & 450 & $10.70 \%$ \\
\hline Some college & 387 & $18.22 \%$ & 590 & $28.37 \%$ & 977 & $23.24 \%$ \\
\hline High School & 95 & $4.47 \%$ & 547 & $26.30 \%$ & 642 & $15.27 \%$ \\
\hline DNF High School & 3 & $0.14 \%$ & 40 & $1.92 \%$ & 43 & $1.02 \%$ \\
\hline \multicolumn{7}{|c|}{ Household Income ( $\mathrm{n}=1062 \mathrm{eH}$ couples; 1040 comparison couples, 2102 total couples) } \\
\hline$\$ 0 /$ Decline & 21 & $0.99 \%$ & 11 & $0.53 \%$ & 32 & $0.76 \%$ \\
\hline Less than $\$ 20 \mathrm{~K}$ & 12 & $0.57 \%$ & 104 & $5.00 \%$ & 116 & $2.76 \%$ \\
\hline$\$ 20 \mathrm{~K}$ to $\$ 40 \mathrm{~K}$ & 130 & $6.12 \%$ & 503 & $24.18 \%$ & 633 & $15.06 \%$ \\
\hline$\$ 40 \mathrm{~K}$ to $\$ 60 \mathrm{~K}$ & 362 & $17.04 \%$ & 559 & $26.88 \%$ & 921 & $21.91 \%$ \\
\hline$\$ 60 \mathrm{~K}$ to $\$ 125 \mathrm{~K}$ & 1062 & $50.00 \%$ & 739 & $35.53 \%$ & 1801 & $42.84 \%$ \\
\hline$\$ 125 \mathrm{~K}$ to $\$ 250 \mathrm{~K}$ & 473 & $22.27 \%$ & 145 & $6.97 \%$ & 618 & $14.70 \%$ \\
\hline More than $\$ 250 \mathrm{~K}$ & 64 & $3.01 \%$ & 19 & $0.91 \%$ & 83 & $1.97 \%$ \\
\hline \multicolumn{7}{|c|}{ Children from Current Marriage } \\
\hline 0 & 723 & $68.08 \%$ & 294 & $28.27 \%$ & 1017 & $48.38 \%$ \\
\hline 1 & 269 & $25.33 \%$ & 247 & $23.75 \%$ & 516 & $24.55 \%$ \\
\hline 2 & 64 & $6.03 \%$ & 316 & $30.39 \%$ & 380 & $18.08 \%$ \\
\hline 3 & 6 & $0.57 \%$ & 136 & $13.08 \%$ & 142 & $6.76 \%$ \\
\hline 4 & 0 & & 28 & $2.69 \%$ & 28 & $1.33 \%$ \\
\hline 5 or more & 0 & & 19 & $1.83 \%$ & 19 & $0.90 \%$ \\
\hline
\end{tabular}

Notable differences in most demographics, such as age-at-marriage and years married, can be observed in the overall sample. Of 1,556 initial participants recruited by SSI, 1,040 spouses participated (70\%), resulting in 1,040 participating 'comparison' couples (7\% overall response). This $7 \%$ is consistent with response rates generally observed when conducting online recruitment with unaffiliated samples. The 7\% response rate is a conservative estimate that ignores the degree to which recruitment emails are actually discarded by the receiver or his/her mail agent without being read. From the Online Matched pool, 3,471 couples were sent recruitment emails. This recruitment resulted in participation from 1,487 initial participants (43\% response rate) from which 1,062 spouses also participated (71\%) resulting in 1,062 couples matched by the online service ( $31 \%$ overall response to email recruitment). Both Online Matched and Comparison couples should be treated as 'samples of convenience'. No propensity 
weighting was conducted on the current data to correct for observed biases. Although it is likely that the SSI sample comprises a representative example of online users who are married and interested in taking on line surveys, and the online matched sample is representative of online users who have used an online matchmaking system and are interested in taking surveys, it is not known to what extent they are representative of either online users in general, or the greater general population.

Analytic Strategy: Two primary hypotheses were tested in the current study: First, we hypothesized that mate selection could be substantively altered through the effects of an online matching system. Second, we hypothesised that the Online Matched relationships, based at least in part on the online matching mechanism, would be observed to be more successful in regards to relationship quality. To test our first hypothesis intra-dyad profile correlations within the sample of Online Matched couples were compared to those within the sample of Comparison couples. Our second hypothesis, that effects in selection had a meaningful effect on marital quality, was tested by comparing marriage quality scores for Online Matched and Comparison couples with ANCOVA.

An initial ANCOVA was conducted in which husband's age, wife's age, husband's age at marriage, wife's age at marriage, years married, current annual household income, and number of children from current marriage were entered as covariates prior to testing group differences on the dependent measure of marital quality. A secondary ANCOVA was conducted using subsamples of Online Matched and Comparison participants who had been matched on two key demographic variables (Length of marriage and age at marriage). The goal of the secondary analysis was to control through selection for the very large differences between Online Matched and Comparison couples on marriage length and age at marriage observed in the overall samples. The criteria for being included in the paired analysis were a marriage age of 24 or greater, and a marriage length of 5 years or less. For the paired sample, one couple from the Online Matched sample was randomly selected to match each Comparison couple based on $+/-1$ year of marriage length. This resulted in a sample of 314 couples, 157 matched by the eHarmony online matchmaking system, and 157 who selected their mates under unfettered conditions. Demographics for the paired samples are shown below in Table 2. 
Table 2

Demographics for Paired Sample*

\begin{tabular}{|c|c|c|c|c|c|c|}
\hline \multirow[b]{3}{*}{ Measure } & \multicolumn{6}{|c|}{ Group } \\
\hline & \multicolumn{2}{|c|}{$\begin{array}{l}\text { Online } \\
\text { Matched }(\mathrm{N}=314)\end{array}$} & \multicolumn{2}{|c|}{ Comparison $(\mathrm{N}=314)$} & \multicolumn{2}{|c|}{ Total $(\mathrm{N}=628)$} \\
\hline & Mean & $\mathrm{SD}$ & Mean & SD & Mean & SD \\
\hline Age & 40.76 & 10.64 & 37.92 & 8.83 & 39.34 & 9.87 \\
\hline Age at Marriage & 38.33 & 10.49 & 35.18 & 8.78 & 36.75 & 9.79 \\
\hline Years Married & 2.44 & 1.41 & 2.75 & 1.70 & 2.59 & 1.57 \\
\hline Measure & Count & $\%$ & Count & $\%$ & Count & $\%$ \\
\hline \multicolumn{7}{|l|}{ Education } \\
\hline Doctorate & 14 & $4.5 \%$ & 8 & $2.5 \%$ & 22 & $3.5 \%$ \\
\hline Masters & 81 & $25.8 \%$ & 26 & $8.3 \%$ & 107 & $17.0 \%$ \\
\hline Bachelors & 111 & $35.4 \%$ & 94 & $29.9 \%$ & 205 & $32.6 \%$ \\
\hline Associates & 29 & $9.2 \%$ & 45 & $14.3 \%$ & 74 & $11.8 \%$ \\
\hline Some college & 63 & $20.1 \%$ & 75 & $23.9 \%$ & 138 & $22.0 \%$ \\
\hline High School & 15 & $4.8 \%$ & 63 & $20.1 \%$ & 78 & $12.4 \%$ \\
\hline DNF High School & 1 & $0.3 \%$ & 3 & $1.0 \%$ & 4 & $0.6 \%$ \\
\hline \multicolumn{7}{|l|}{ Household Income } \\
\hline$\$ 0$ & 3 & $1.0 \%$ & 4 & $1.3 \%$ & 7 & $1.1 \%$ \\
\hline Less than $\$ 20 \mathrm{~K}$ & 0 & $0.0 \%$ & 22 & $7.0 \%$ & 22 & $3.5 \%$ \\
\hline$\$ 20 \mathrm{~K}$ to $\$ 40 \mathrm{~K}$ & 24 & $7.6 \%$ & 56 & $17.8 \%$ & 80 & $12.7 \%$ \\
\hline$\$ 40 \mathrm{~K}$ to $\$ 60 \mathrm{~K}$ & 61 & $19.4 \%$ & 100 & $31.8 \%$ & 161 & $25.6 \%$ \\
\hline$\$ 60 \mathrm{~K}$ to $\$ 125 \mathrm{~K}$ & 159 & $50.6 \%$ & 104 & $33.1 \%$ & 263 & $41.9 \%$ \\
\hline$\$ 125 \mathrm{~K}$ to $\$ 250 \mathrm{~K}$ & 60 & $19.1 \%$ & 23 & $7.3 \%$ & 83 & $13.2 \%$ \\
\hline More than $\$ 250 \mathrm{~K}$ & 7 & $2.2 \%$ & 5 & $1.6 \%$ & 12 & $1.9 \%$ \\
\hline \multicolumn{7}{|l|}{ Children } \\
\hline 0 & 208 & $66.2 \%$ & 187 & $59.6 \%$ & 395 & $62.9 \%$ \\
\hline 1 & 68 & $21.7 \%$ & 65 & $20.7 \%$ & 133 & $21.2 \%$ \\
\hline 2 & 29 & $9.2 \%$ & 43 & $13.7 \%$ & 72 & $11.5 \%$ \\
\hline 3 & 6 & $1.9 \%$ & 16 & $5.1 \%$ & 22 & $3.5 \%$ \\
\hline 4 & 1 & $0.3 \%$ & 1 & $0.3 \%$ & 2 & $0.3 \%$ \\
\hline 5 or more & 2 & $0.6 \%$ & 2 & $0.6 \%$ & 4 & $0.6 \%$ \\
\hline
\end{tabular}

$*$ Matched sample $=$ minimum age at marriage of 24 years and max marriage length of 5 years.

Finally, since the DAS is a multi-factor scale, a multivariate ANCOVA analysis of the four subscales (e.g., Dyadic Consensus, Dyadic Satisfaction, Affectional Expression and Dyadic Cohesion) was also conducted in both the overall and paired samples in order to determine the breadth and scope of differences between the Online Matched and Comparison groups in regards to marital functioning.

Procedure: Members of married couples separately completed an online questionnaire between November 1 and December 15, 2007 accessed via a unique personalized URL link in the recruitment email. The median interval between spouse 
participation was 3.75 days, with the survey taking 40 minutes to complete on average. The online questionnaire was comprised of several hundred items designed and fielded as part of ongoing validation studies for a proprietary online matching system currently in broad use. The questionnaire included items assessing personality, affect and values. The questionnaire included the Dyadic Adjustment Scale (DAS) (Spanier, 1976). The DAS is a 32-item questionnaire comprising four subscales: Dyadic Consensus, Dyadic Satisfaction, Affectional Expression and Dyadic Cohesion. Summed scores on these four scales provide a metric of overall Dyadic Adjustment. For the current study, summed within couple scores on Dyadic Adjustment were used as the dependent measure of marital relationship quality.

\section{Results}

Hypothesis 1: Online matchmaking can affect mate selection. Within-dyad profile correlations were computed for 124 items from the questionnaire representing a broad range of personality, affect and values related measurements. A sample of the items used to generate the profile correlations are shown in Table 7. Items are grouped for ease of reading into factors extracted through an exploratory Principal Components Analysis rotated by an Equamax rotation with Kaiser normalization. Please note that these factors were not used in the analyses presented, nor do they comprise formulistic factors or scales used by the matchmaking system.

Results summarized in Figure 1 show that in the overall sample, a significant difference was observed $(F=135.45(1,2100), p<.001)$ between the mean squared profile correlation among Online Matched $(M=0.76$, std $=.33)$ couples and Comparison couples $(M=0.58$, std $=.38)$. A strong relation between profile correlations and summed couple Total DAS scores was observed in the overall sample, $r(2102)=0.63, p<.001$. These findings were replicated in the paired sample. A significant difference was observed $(F=135.45(1,2100), p<.001)$ between Online Matched $(M=0.79$, std $=.32)$ and Comparison couples $(M=0.56$, std $=.35)$. Finally, in an exploratory analysis a strong relation between profile correlations and summed couple Total DAS scores was observed in the paired sample, $r(314)=0.65, p<.001$. 
Figure 1. Mean Profile Correlations: Online Matched vs. Comparison Couples (Overall Sample)

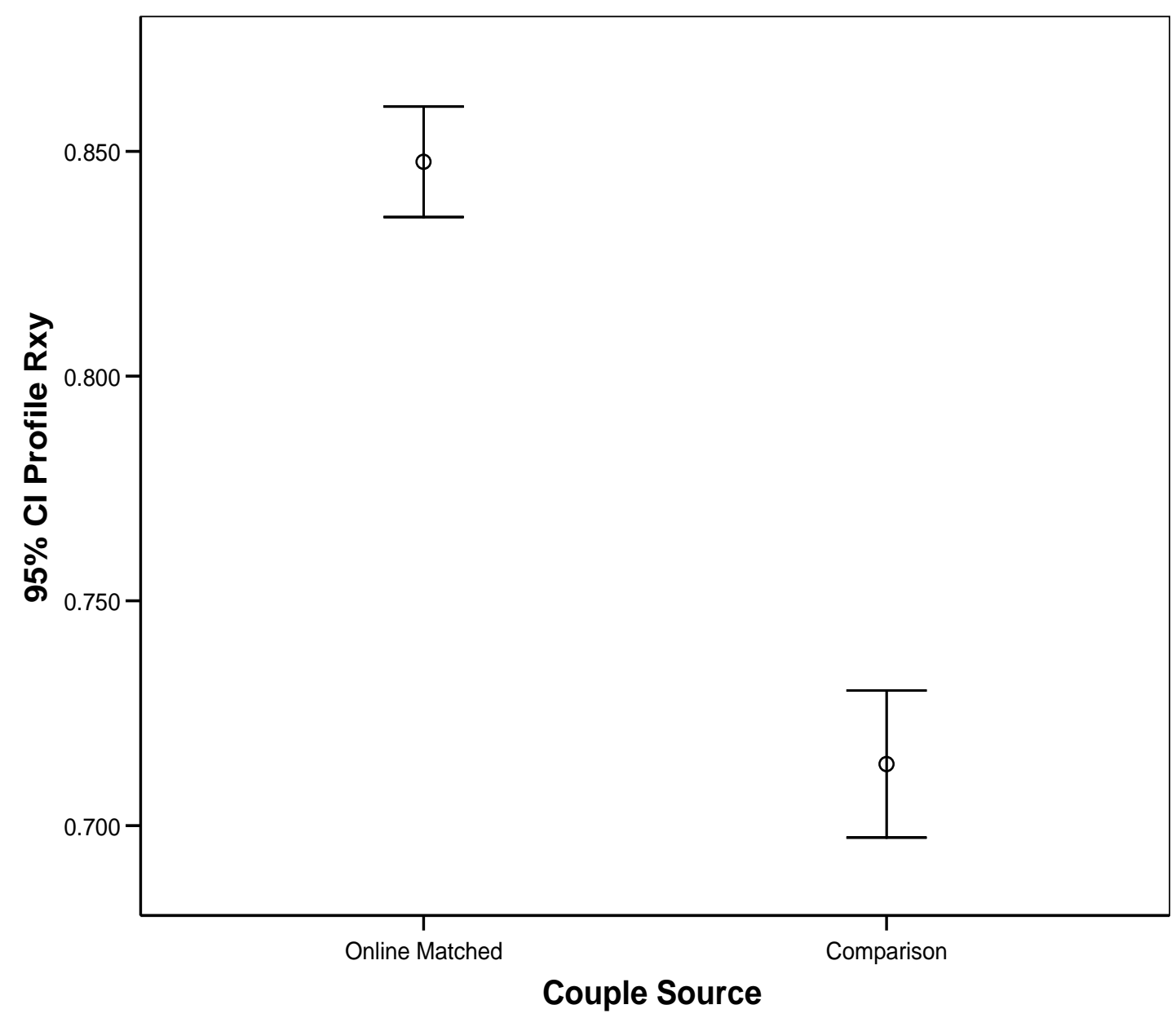

Hypothesis 2: Mate selection constrained by matchmaking will result in better relationships. In order to control for possible confounds in testing this hypothesis, key demographics were controlled both statistically and, in a secondary analysis, through sampling design. Descriptive statistics for the overall sample on all subscales and overall scores on the DAS are shown in Table 3. Both primary and secondary ANCOVA tests indicated that Online Matched couples had significantly higher scores than Comparison couples on summed couple Total Dyadic Adjustment scores (Table 4). Descriptive statistics for the paired sample on all subscales and overall scores on the DAS are shown in Table 5. 
Table 3

Average Marital Quality Scores by Group (Overall Sample)

\begin{tabular}{|c|c|c|c|c|c|c|}
\hline \multirow[b]{2}{*}{ Dependent Measure } & \multicolumn{2}{|l|}{ Online } & Online & Comparison & Online & Comparison \\
\hline & \multicolumn{2}{|c|}{ Mean } & \multicolumn{2}{|c|}{ Standard Deviation } & \multicolumn{2}{|c|}{ Sample Size } \\
\hline Dyadic Consensus & 107.11 & 98.27 & 10.07 & 14.03 & 1062 & 1040 \\
\hline Dyadic Satisfaction & 79.31 & 71.74 & 6.66 & 10.77 & 1062 & 1040 \\
\hline Affectional Expression & 19.49 & 17.17 & 3.39 & 4.36 & 1062 & 1040 \\
\hline Dyadic Cohesion & 32.59 & 29.49 & 4.50 & 5.97 & 1062 & 1040 \\
\hline Couple Total DAS & 238.51 & 216.67 & 20.06 & 29.93 & 1062 & 1040 \\
\hline
\end{tabular}

Table 4

ANCOVA Estimated Couple DAS Scores and F Tests by Group (Overall Sample)

\begin{tabular}{|c|c|c|c|c|c|c|c|}
\hline \multirow[b]{2}{*}{ Measure } & \multirow[b]{2}{*}{ Group } & \multirow{2}{*}{$\begin{array}{c}\text { Est. } \\
\text { Mean }\end{array}$} & \multirow{2}{*}{$\begin{array}{l}\text { Std. } \\
\text { Error }\end{array}$} & \multicolumn{2}{|c|}{$95 \% \mathrm{CI}$} & \multirow{2}{*}{$\begin{array}{c}F \\
(1,2054)\end{array}$} & \multirow[b]{2}{*}{ Sig } \\
\hline & & & & Lower & Upper & & \\
\hline \multirow[t]{2}{*}{ Dyadic Consensus $^{(a)}$} & Matched & 106.75 & 0.46 & 105.84 & 107.65 & 109.49 & 0.001 \\
\hline & Comparison & 98.61 & 0.48 & 97.67 & 99.55 & & \\
\hline \multirow[t]{2}{*}{ Dyadic Satisfaction $^{(a)}$} & Matched & 79.16 & 0.34 & 78.49 & 79.83 & 161.92 & 0.001 \\
\hline & Comparison & 71.86 & 0.35 & 71.17 & 72.55 & & \\
\hline \multirow[t]{2}{*}{ Affectional Expression ${ }^{(a)}$} & Matched & 19.33 & 0.15 & 19.04 & 19.62 & 64.23 & 0.001 \\
\hline & Comparison & 17.33 & 0.15 & 17.03 & 17.63 & & \\
\hline \multirow[t]{2}{*}{ Dyadic Cohesion $^{(a)}$} & Matched & 32.44 & 0.20 & 32.05 & 32.84 & 68.00 & 0.001 \\
\hline & Comparison & 29.66 & 0.21 & 29.25 & 30.06 & & \\
\hline \multirow[t]{2}{*}{ Couple Total DAS ${ }^{(b)}$} & Matched & 237.68 & 0.97 & 235.77 & 239.58 & 153.81 & 0.001 \\
\hline & Comparison & 217.46 & 1.00 & 215.49 & 219.43 & & \\
\hline
\end{tabular}

(a) Covariates appearing in the multivariate model of the subscales are evaluated at the following values: husband age $=41.97$, wife age $=39.75$, husband age at marriage $=33.86$, wife age at marriage $=31.81$, years married $=7.45$, husband's education $=3.80$, wife's Education $=3.85$, children from current Marriage $=.96$, annual household income $=4.56$.

(b) Covariates appearing in the univariate model of the combined subscales (Total DAS) are evaluated at the following values: husband age $=41.97$, wife age $=39.75$, husband age at marriage $=33.86$, wife age at marriage $=31.81$, years married $=7.45$, husband education $=3.80$, wife education $=3.85$, current children $=.96$, annual household income $=4.56$

Table 5

Average Marital Quality Scores by Group (Paired Sample)

\begin{tabular}{|c|c|c|c|c|c|c|}
\hline \multirow[b]{2}{*}{ Dependent Measure } & $\begin{array}{c}\text { Online } \\
\text { Matche } \\
\mathrm{d}\end{array}$ & $\begin{array}{c}\text { Compariso } \\
\mathrm{n}\end{array}$ & $\begin{array}{c}\text { Online } \\
\text { Matche } \\
\mathrm{d}\end{array}$ & $\begin{array}{c}\text { Compariso } \\
\mathrm{n}\end{array}$ & $\begin{array}{c}\text { Online } \\
\text { Matche } \\
\mathrm{d}\end{array}$ & $\begin{array}{c}\text { Compariso } \\
\mathrm{n}\end{array}$ \\
\hline & \multicolumn{2}{|c|}{ Mean } & \multicolumn{2}{|c|}{ Standard Deviation } & \multicolumn{2}{|c|}{ Sample Size } \\
\hline Dyadic Consensus & 107.18 & 99.29 & 9.05 & 12.94 & 157 & 157 \\
\hline $\begin{array}{l}\text { Dyadic Satisfaction } \\
\text { Affectional }\end{array}$ & 79.46 & 72.57 & 5.92 & 10.46 & 157 & 157 \\
\hline Expression & 19.38 & 17.83 & 3.34 & 4.34 & 157 & 157 \\
\hline Dyadic Cohesion & 33.02 & 30.13 & 5.01 & 5.97 & 157 & 157 \\
\hline Total DAS & 239.04 & 219.82 & 19.02 & 27.53 & 157 & 157 \\
\hline
\end{tabular}


The observed means and comparisons between the paired samples in which all marriages were of 5 years or less were not notably different from those observed in the overall sample. Table 6 shows that in the paired sample, after statistically controlling for the effects described above, Online Matched couples again scored significantly higher on summed Total than Comparison couples. Online Matched couples were also observed to score significantly higher than Comparison couples on all summed individual subscales of the DAS in both the primary analysis using the overall sample, and in the secondary analysis using the paired sample.

Table 6

ANCOVA Estimated Couple DAS Scores and F Tests by Group (Paired Sample)

\begin{tabular}{|c|c|c|c|c|c|c|c|}
\hline \multirow[b]{2}{*}{ Measure } & \multirow[b]{2}{*}{ Group } & \multirow{2}{*}{$\begin{array}{c}\text { Est. } \\
\text { Mean }\end{array}$} & \multirow{2}{*}{$\begin{array}{l}\text { Std. } \\
\text { Error }\end{array}$} & \multicolumn{2}{|c|}{$95 \% \mathrm{CI}$} & \multirow{2}{*}{$\begin{array}{c}F \\
(1,2054) \\
\end{array}$} & \multirow[b]{2}{*}{ Sig } \\
\hline & & & & Lower & Upper & & \\
\hline \multirow[t]{2}{*}{ Dyadic Consensus ${ }^{(a)}$} & Matched & 106.69 & 0.92 & 104.87 & 108.50 & 25.58 & 0.001 \\
\hline & Comparison & 99.78 & 0.92 & 97.97 & 101.60 & & \\
\hline \multirow[t]{2}{*}{ Dyadic Satisfaction $^{(\mathrm{a})}$} & Matched & 79.46 & 0.70 & 78.09 & 80.84 & 44.70 & 0.001 \\
\hline & Comparison & 72.56 & 0.70 & 71.19 & 73.93 & & \\
\hline \multirow[t]{2}{*}{ Affectional Expression $^{(a)}$} & Matched & 19.38 & 0.32 & 18.76 & 20.01 & 10.81 & 0.001 \\
\hline & Comparison & 17.83 & 0.32 & 17.20 & 18.46 & & \\
\hline \multirow[t]{2}{*}{ Dyadic Cohesion $^{(a)}$} & Matched & 32.88 & 0.45 & 31.99 & 33.78 & 15.22 & 0.001 \\
\hline & Comparison & 30.26 & 0.45 & 29.37 & 31.16 & & \\
\hline \multirow[t]{2}{*}{ Total DAS $^{(b)}$} & Matched & 238.42 & 1.94 & 234.60 & 242.24 & 39.04 & 0.001 \\
\hline & Comparison & 220.44 & 1.94 & 216.62 & 224.26 & & \\
\hline
\end{tabular}

(a) Covariates appearing in the multivariate model of the subscales are evaluated at the following values: husband age $=40.56$, wife age $=38.13$, husband age at marriage $=37.97$, wife age at marriage $=35.54$, years married rev $=2.57$, husband education $=3.74$, wife education $=3.69$, children from current marriage $=.56$, annual household income $=4.47$.

(b) Covariates appearing in the univariate model of the combined subscales (Total DAS) are evaluated at the following values: husband age $=40.56$, wife age $=38.13$, husband age at marriage $=37.97$, wife age at marriage $=35.54$, years married $=2.57$, husband education $=3.74$, wife education $=3.69$, children from current marriage $=.56$, annual household income $=4.47$. 
Table 7. Sample items used for computing profile correlations

\begin{tabular}{|c|c|}
\hline Factor & Sample items \\
\hline Social Isolation & $\begin{array}{l}\text { (How often do you feel) Isolated from others? } \\
\text { (How often do you feel) That you are no longer close to anyone? } \\
\text { (How often do you feel) That no one really knows you well? }\end{array}$ \\
\hline $\begin{array}{l}\text { Anger Management } \\
\text { /Dysthimia }\end{array}$ & $\begin{array}{l}\text { (How well does the following describe you) I get angry easily. } \\
\text { (How well does the following describe you) Irritable } \\
\text { (How well does the following describe you) I get upset easily }\end{array}$ \\
\hline Depression & $\begin{array}{l}\text { (How often in the past } 30 \text { days) I felt depressed. } \\
\text { (How often in the past } 30 \text { days) I felt sad. } \\
\text { (How often in the past } 30 \text { days) I could not get 'going.' }\end{array}$ \\
\hline Global Affect & $\begin{array}{l}\text { (How well does the following describe you) Satisfied } \\
\text { (How well does the following describe you) Fulfilled } \\
\text { (How well does the following describe you) Happy }\end{array}$ \\
\hline Empathy & $\begin{array}{l}\text { (How well does the following describe you) I think of others first. } \\
\text { (How well does the following describe you) Caring } \\
\text { (How well does the following describe you) Compassionate }\end{array}$ \\
\hline Religiosity & $\begin{array}{l}\text { (How interested are you in) Religious Faith } \\
\text { (How interested are you in) Religious Community } \\
\text { (How interested are you in) Involvement at my Place of Worship }\end{array}$ \\
\hline Body Image & $\begin{array}{l}\text { (How well does the following describe you) When I see good-looking people, } \\
\text { I wonder about how my own looks measure up. } \\
\text { (How well does the following describe you) When I meet people for the first } \\
\text { time, I wonder what they think about how I look. } \\
\text { (How well does the following describe you) In my everyday life, lots of things } \\
\text { happen that make me think about what I look like. }\end{array}$ \\
\hline Romantic Affect & $\begin{array}{l}\text { (How well does the following describe you) Romantic } \\
\text { (How well does the following describe you) Sensual } \\
\text { (How well does the following describe you) Passionate }\end{array}$ \\
\hline Humor & $\begin{array}{l}\text { (How well does the following describe you) I have an ability to make others } \\
\text { laugh } \\
\text { (How well does the following describe you) Witty } \\
\text { (How well does the following describe you) I often see humor in everyday life }\end{array}$ \\
\hline Conscientiousness & $\begin{array}{l}\text { (How well does the following describe you) I am always prepared. } \\
\text { (How well does the following describe you) I pay attention to details. } \\
\text { (How well does the following describe you) I am well-informed. }\end{array}$ \\
\hline Conflict Resolution & $\begin{array}{l}\text { (How well does the following describe you) I try to resolve the conflict well } \\
\text { (How well does the following describe you) I try to resolve the conflict } \\
\text { quickly } \\
\text { (How well does the following describe you) I try to understand the other } \\
\text { person }\end{array}$ \\
\hline $\begin{array}{l}\text { Emotional Well Being } \\
\text { /Neuroticism }\end{array}$ & $\begin{array}{l}\text { (How well does the following describe you) Calm } \\
\text { (How well does the following describe you) Patient } \\
\text { (How well does the following describe you) My emotions are generally stable }\end{array}$ \\
\hline Values Idealogy & $\begin{array}{l}\text { (How well does the following describe you) Loyal } \\
\text { (How well does the following describe you) Honest } \\
\text { (How well does the following describe you) Genuine }\end{array}$ \\
\hline Extroversion & $\begin{array}{l}\text { (How well does the following describe you) I am skilled at handling social } \\
\text { situations. } \\
\text { (How well does the following describe you) I make people feel at ease. } \\
\text { (How well does the following describe you) Communicative }\end{array}$ \\
\hline
\end{tabular}


The significantly higher scores observed on all components of the DAS for couples in the Online Match group versus couples in the Comparison group indicates a notably higher degree of relationship quality within the couples introduced by an online matchmaking system. For example, Online Matched couples indicated a higher degree of happiness, optimism and commitment to the success of their relationship than did Comparison couples. As shown in Figure 2, Online Matched couples were notably more likely than other Comparison couples to indicate that they considered their marriage to be "Extremely Happy" or "Perfect" (66\% versus 39\%). In contrast, shown in Figure 3, members of Comparison couples were about twice as likely as Online Matched (37\% versus $18 \%$ ) to indicate that they had ever regretted that they married their current partner. As would be expected in light of the overall pattern of results, the Online Matched couples also appeared to be more committed to their marriages than Comparison couples. As shown in Figure 3, 96\% of Online Match couples indicated that they would do "all I can" to make their marriage succeed, versus $83 \%$ of Comparison couples. In contrast, only $4 \%$ of the Online Matched group indicated that they would merely do "my fair share" or less to make their marriage succeed, versus $17 \%$ of Comparison couples.

In order to more easily quantify the impact of the mean differences observed, couple total DAS scores were also coded into two groups, those above the $75^{\text {th }}$ percentile for the Comparison couples, and those that were under the $75^{\text {th }}$ percentile. Based on this criterion, the impact of the mean differences reported here can be observed in terms of relative probability of a relationship inhabiting the top quartile of relationship quality as exists without intervention. By this metric, 59.9\% of the Online Matched couples were observed to reside in the top quartile. This represents a notable and significant $130 \%$ improvement on the base-rate probability of $25 \%, x^{2}(1, N=2102)$ $=256.97, p<.001)$.

\section{Discussion}

Current results suggest that online matchmaking services are capable of altering some fundamental characteristics of intimate relationships. Specifically, the current data supports the conclusion that online matching affected both mate selection and relationship quality. Couples who married after meeting through a system that constrains selection opportunities based on traits observed in empirical research to be 
positively related to marriage quality, were found to be much more similar on basic personality traits than couples who met through unfettered means. Further, couples who were introduced based on this system demonstrated a significantly higher level of marital quality than comparison couples, and evidenced a significant and notably higher probability of residing in the top tier of marital functioning.

Online matchmaking can be argued to represent a technological implementation of some of the earlier paradigms of modern relationship research. By matching singles based on their personality, affect and value traits the online matchmaking system tested in the current study is leveraging the fundamental theory that basic qualities of the individuals within a marriage, measurable before the onset of a relationship, predict aspects of success in the marriage relationship. This position was well argued as early as 1953 when Burgess and Wallin summarized the pioneering work of Burgess and Cottrell, King, Locke, Terman, Kirkpatrick, and others dating as far back as 1928. It has taken almost a century, and the development of an almost all-pervasive communication medium such as the Internet, to create a method by which prescriptive interventions based on these theories can be developed and implemented at a broad level.

It is hardly surprising to see evidence that unaided selection can be improved upon. Although assortative mate selection has been shown on many of the traits where homogamy has been linked to relationship success, no evidence has ever suggested that people commonly make optimal choices in regards to the amount or type of traits where they seek or achieve similarity with their partners. Indeed, the rate of divorce in America has long suggested to some of those interested in the predictive power of personal traits and similarities in marital success that the qualities most likely to account for the lion's share of variance in mate selection as it naturally occurs are at best only weakly associated with the qualities most important to a match should optimal outcomes be desired (Warren, 1992).

It should be noted that the services of the matchmaking system providing the matched couples assessed in the current study are almost universally purchased by the match recipients. It can therefore be assumed that matches must first achieve subjective approval by the recipients before a relationship is initiated. In other words, although the matchmaking system tested is based on models that focus on objective relationship outcomes, only matches that also satisfied the personal criteria of users resulted in relationships that could be included in the analyses. There is no indication that users of online dating sites are less inclined to assortative selection. Indeed, a recent examination 
of 65,000 online daters users significantly preferred others who were similar in regards to attributes such as marital history, desire to have children, physical build, physical attractiveness, and smoking habits (Fiore \& Donath, 2005). One can assume, therefore, that both populations of couples may represent partners that satisfy the same subjective qualities of similarity. This provides some support for the idea that subjective criteria related to mate selection are, at best, less than optimal in regards to relationship success and that objective evaluation of traits known to relate to marital quality not only enhances the level of homogamy observed in a relationship but also the reported level of marital satisfaction.

The present report is of necessity limited in scope by the fact that the algorithms used to match individuals must remain proprietary. However, the evidence that singles matched according to a system based on the assessment and modelling of married couples that has been observed previously (Carter \& Snow, 2004) to provide a significant benefit to its users is a compelling argument for the value of a generic principle of assisted mate selection through assessment and matching of singles. It also provides further support that important individual traits can be reliably and validly assessed over the internet.

Another limitation of the current study is its reliance on people who have chosen to participate in online research regarding their marriage. In addition to whatever differences may systematically exist between these marrieds and their offline or nonresponding contemporaries, it is possible that some desire to be identified as a 'success' may have provided additional and differential motivation to the online matched respondents to be included in the sample. It is hoped that efforts in the current study to standardize recruitment and incentives across groups, and the length of time which separated the identification of online matched couples through opt-in and their recruitment for this study, worked to mitigate these limitations. However, it will be important that future research attempt to use respondents selected through a more systematically random method.

Marital matchmaking, whether online or offline, implies that levels and similarities within dyads on important traits can be manipulated through selection. Generally speaking, matchmakers can be seen to have two goals. The first is to create matches which are subjectively pleasing to the clients. In other words, matches must achieve a level of surface validity (i.e., be pleasing to the individuals purchasing the matchmaking service). The second is to create matches which have objectively good 
relationship outcomes. For modern matchmakers in the United States, the objective outcome of a match is generally stated to be lasting love and marital commitment. Such research as exists examining online matchmaking has focused primarily on the degree to which subjective quality of matches is achieved through the interaction between daters and the tools provided by dating sites (Baker, 2002; Ellison, Heino \& Gibbs, 2006; Gibbs, Ellison, Heino, 2006; Hitsch, Hortacsu \& Ariely, 2005; Whitty \& Gavin, 2001). In contrast, the current paper presents an example of the degree to which the objective relationship outcomes of matches can be affected by an online matchmaking system. The current results suggest that measurement of individual traits and restriction of introductions based on a systematic consideration of traits within potential couples based on the empirical study of earlier cohorts of married couples can have a powerful and long-lasting impact on the quality of the marital relationships subsequently formed.

The current results illustrate the significant positive impact on marital quality achieved by an online matching of singles based on a model of intra-couple compatibility before subjective criteria assumedly are applied by those singles to make a selection or initiate a relationship. Existing programs focusing on strengthening relationship skills are not addressed by the current findings. Further, the mediational role that similarity plays in relationship quality is not explored in this paper and is the topic of future work. However, in general we do confirm the frequently reported association between similarity and marital quality. These results strongly suggest the need for an increased emphasis on research into the role of both compatibility and selection when it comes to singles seeking or entering long term relationships. Online matchmaking services appear uniquely suited to facilitate as well as benefit from such research.

\section{References}

Acitelli, L. K., Kenny, D. A., \& Weiner, D. (2001). The importance of similarity and understanding of partners' marital ideals to relationship satisfaction. Personal Relationships, 8, 167-185. 
Adams, C. (1946). The prediction of adjustment in marriage. Educational and Psychological Measurement, 6, 185-193.

Anderson, C., Keltner, D., \& John, O. P. (2003). Emotional convergence between people over time. Journal of Personality \& Social Psychology, 84, 1054-1068.

Antill, J. K. (1983). Sex role complementarity versus similarity in married couples. Journal of Personality \& Social Psychology, 45, 145-155.

Aron, A., Aron, E. N., \& Smollan, D. (1992). Inclusion of other in the self scale and the structure of interpersonal closeness. Journal of Personality \& Social Psychology, 63, 596-612.

Baker, A. (2002). What makes an online relationship successful? Clues from couples who met in cyberspace. CyberPsychology \& Behavior, 5, 363-375.

Blood, R. Jr., \& Wolfe, D. (1960). Husbands and wives: The dynamics of married life. New York: Free Press.

Bouchard, T. J. Jr., \& McGue, M. (1981). Familial studies of intelligence: A review. Science, 212, 1055-1059.

Burgess, E.W., \& Cottrell, L.S. (1939). Predicting Success or Failure in Marriage. Englewood Cliffs, NJ : Prentice Hall.

Burgess, E. W. \& Wallin, P. (1953). Engagement and marriage. New York: Lippincott.

Carter, S., \& Snow, C. (2004). Helping Singles Enter Better Marriages Using Predictive Models of Marital Success. Paper presented at the Annual Convention of the American Psychological Society. Chicago, IL.

Crawford, D.W., Houts, R.M., Huston, T.L. \& George, L.J. (2002). Compatibility, Leisure, and satisfaction in marital relationships. Journal of Marriage and the Family, 64, 433-449. 
Ellison, N. Heino, R. \& Gibbs, J. (2006) Managing Impressions Online: SelfPresentation Processes in the Online Dating Environment, Journal of ComputerMediated Communication, 11, 415-441

Feingold, A. (1988). Matching for attractiveness in romantic partners and same-sex friends: A meta-analysis and theoretical critique. Psychological Bulletin, 104, 226-235.

Feng, D., \& Baker, L. (1994). Spouse similarity in attitudes, personality, and psychological well-being. Behavior Genetics, 24, 357-364.

Fowers, B.J. \& Olson, D.H. (1992). Four types of premarital couples : An empirical typology based on PREPARE. Journal of Family Psychology, 6, 10-21.

Fiore, A., \& Donath, J. (2005). Homophily in Online Dating: When Do You Like Someone Like Yourself? Paper presented at the Computer Human Interaction conference (CHI) Portland, Oregon.

Gattis, K. S., Berns, S., Simpson, L. E. \& Christensen, A. (2004). Birds of a feather or strange birds? Ties among personality dimensions, similarity, and marital quality. Journal of Family Psychology, 18, 564-574.

Gaunt, R. (2006). Couple similarity and marital satisfaction: Are similar spouses happier? Journal of Personality, 74, 1401-1420.

Gibbs, J. Ellison, N. \& Heino, R. (2006) Self-Presentation in Online Personals: The Role of Anticipated Future Interaction, Self-Disclosure, and Perceived Success in Internet Dating Communication Research, 33,152

Gonzaga, G. C., Campos, B. \& Bradbury, T. (2007). Similarity, convergence, and relationship satisfaction in dating and married couples. Journal of Personality \& Social Psychology, 93, 34-48. 
Gottman, J. \& Notarius, C. (2000). Decade Review: Observing Marital Interaction. Journal of Marriage and the Family, 62, 927-947.

Hitsch, G. J., Hortacsu, A. \& Ariely, D. (2006) What Makes You Click: An Empirical Analysis of Online Dating. Paper presented at the American Economic Association meeting.

Hollingshead, A. B. (1950). Cultural factors in the selection of marriage mates. American Sociological Review, 15, 619-627.

Huston, T. L., \& Houts, R. M. (1998). The psychological infrastructure of courtship and marriage: The role of personality and compatibility in romantic relationships. In T. Bradbury (Ed.), The developmental course of marital dysfunction (pp. 114151). New York: Cambridge University Press.

Karney, B.R. \& Bradbury, T.N. (1995). The longitudinal course of marital quality and stability : A review of theory, method, and research. Psychological Bulletin, 118, 3-34.

Kim, H. K., Capaldi, D. M. \& Crosby, L. (2007). Generalizability of Gottman and Colleagues' Affective Process Models of Couples' Relationship Outcomes. Journal of Marriage and Family, 69, 55-72

Kurdek, L. (1993). Predicting marital dissolution: A 5-year prospective longitudinal study of newlywed couples. Journal of Personality \& Social Psychology, 64, 221-242.

Luo, S. \& Klohnen, E. C. (2005). Assortative Mating and Marital Quality in Newlyweds: A Couple-Centered Approach. Journal of Personality \& Social Psychology, 88, 304-326

Murstein, B. I., \& Williams, P. D. (1985). Assortative matching for sex-role and marriage adjustment. Personality and Individual Differences, 6, 195-201. 
Richard, L. S., Wakefield Jr, J. A., \& Lewak, R. (1990). Similarity of personality variables as predictors of marital satisfaction: a Minnesota Multiphasic Personality Inventory (MMPI) item analysis. Personality and Individual Differences, 11, 39-43.

Russell, R., J., \& Wells, P. A. (1991). Personality similarity and quality of marriage. Personality and Individual Differences, 12, 407-412.

Schulz, M., Brennan, R., Cowan, P. \& Cowan, C. (2004) Coming Home Upset: Gender, Marital Satisfaction, and the Daily Spillover of Workday Experience Into Couple Interactions, Journal of Family Psychology, 18, 250-263

Shiota, M. N., \& Levenson, R. W. (2007). Birds of a feather don't always fly farthest: Similarity in Big Five personality predicts more negative marital satisfaction trajectories in long-term marriages, Psychology and Aging, 22, 666-675.

Smith, D.A., Vivian, D., \& O’Leary, K.D. (1990). Longitudinal prediction of marital discord from premarital expressions of affect. Journal of Consulting and Clinical Psychology, 58, 790-798.

Snyder, D.K. (1979). Multidimensional assessment of marital satisfaction. Journal of Marriage and the Family, 41, 813-823.

Spanier, G.B. (1976). Measuring dyadic adjustment: New scales for assessing the quality of marriage and similar dyads. Journal of Marriage and the Family, 38, $15-28$.

Terman, L.M., Buttenweiser, P., Ferguson, L.W., Johnson, W.B., \& Wison, D.P. (1938). Psychological factors in marital happiness. New York: McGraw-Hill.

Tharp, R. (1963) Psychological patterning in marriage. Psychological Bulletin, 60, 97117. 
Warren, N. (1992). Finding the love of your life: Ten principles for choosing the right marriage partner. Tyndale House Publishers, Wheaton, IL.

Whitty, M., \& Gavin, J. (2001). Age/sex/location: Uncovering the social cues in the development of online relationships. Cyberpsychology \& Behavior, 4, 623-639.

Received: August 27th, 2009 Accepted: December 30th, 2009 